\title{
Use of Personal Protective Equipment
}

\section{Purpose}

It is a requirement of the School of Chemistry and the University that appropriate personal protective equipment (PPE) be employed to minimise risks which may be present within a laboratory or workplace. This guideline discusses the various basic types of which are available to laboratory workers, briefly outlining their use, application and maintenance.

\section{Scope}

This procedure applies to all personnel working in the School of Chemistry laboratories, including undergraduates completing practical sessions within teaching laboratories

\section{References}

AS/NZS 2243.1 (2005): Safety in laboratories - Planning and operational Aspects AS/NZS 1336 (1997): Recommended practices for occupational eye protection AS/NZS 2210.1:1994 Occupational protective footwear Part 1: Guide to selection, care and use AS/NZS 1715:2009 Selection, use and maintenance of respiratory protective equipment PER-OHS-GUI-048.4 UOW Laboratory Safety Guidelines PER-OHS-GUI-048.4 UOW Clothing and Protective Equipment Guidelines OSHA 3151-12R (2003) Personal Protective Equipment

\section{Definitions}

$P P E$ - Personal Protective Equipment

\section{Procedure}

\subsection{General}

Safety glasses, long sleeved and buttoned up lab coat, fully enclosed shoes are the mandatory, minimum personal protective equipment (PPE) required by School of Chemistry for lab workers working in a laboratory containing hazardous materials. Tying hair back and wearing appropriate gloves is also recommended in many situations. Visitors to a lab are required to wear safety glasses. These are available on the entrance door of each research lab.

\section{Failure to wear appropriate PPE can result in denial of entry to a laboratory!}

A hazard assessment should be undertaken to determine the most appropriate control to minimise exposure to a hazard. Controls superior to the use of PPE are methods involving elimination, substitution, engineering, or administration. If these methods are not feasible or do not provide sufficient protection, then personal protective equipment may be a chosen control. All PPE selected should be: appropriate to the hazard; meet Australian Standard; clean and fit the user. In some cases, such as a respirator, training in the correct use and maintenance may be required. For hazardous materials always consult the MSDS which will list recommended PPE.

\section{PPE is only effective if you wear and use it correctly !}

Potential hazards within the school may include:-

- Splashes from liquid chemicals particularly acids or caustic liquids,

- Chemical gases or vapours

- Harmful dusts ( silica)

- Impact / penetration / puncture particularly from broken glass, scalpels and syringe needles

- Cryogens

- Irritants and lachrymators

- Light and laser radiation

- Biological materials

- Heat and Cold

- Noise 
Please refer to Appendix A: Laboratory tasks, hazards and recommended PPE. A variety of personal protective equipment can be used to minimise the risks of these hazards.

\subsection{Eye and Face Protection}

\subsubsection{Safety Glasses}

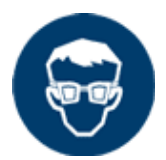

A wide range of safety glasses are available including scratch resistant, ultra-light weight, anti-fog and wrap around. Frames made of metal or plastic have impact-resistant lenses and side shields are available on some models. It is important to get a pair of safety glasses which are comfortable, do not visually impar the user but also provide optimum protection. If safety glasses become scratched, throw them out and replace. Glasses should be washed periodically with soap and water.

Contact lenses and prescription glasses DO NOT provide adequate eye protection. Contact lenses have the potential to actually cause and/or increase injury. Prescription safety glasses or 'overspecs' should be worn.

\subsubsection{Safety Goggles}

If there is risk from chemical splashes then safety goggles are recommended. Goggles are tight-fitting, completely covering the eyes and area immediately surrounding the eyes. They can provide protection from impact, dust and splashes. Some goggles will fit over prescription glasses.

\subsubsection{Laser Safety Goggles}

Laser radiation can be extremely dangerous to the unprotected eye. Direct, reflected or stray beams can cause permanent eye damage. Laser retinal burns can be painless, so it is essential that appropriate eye protection is worn

The type of laser safety goggles used depends upon the class of laser in use. Laser safety goggles should protect for the specific wavelength of the laser. Make ABSOLUTELY SURE the eyewear you're about the put on is the correct protection for the wavelength(s) in use. Laser safety goggles should be labelled with the laser wavelengths for which they are used, the optical density of those wavelengths and the visible light transmission. Note laser Safety training is required for class $3 \mathrm{~b}$ and 4 laser users.

\subsubsection{Face Shields}

Face shields have transparent sheets of plastic which cover the face and protect against potential splashes or sprays of hazardous liquids and dust. The head piece is adjustable and should fit snugly. On most models of face shields, replacement visors can be purchased.

They are recommended when transferring cryogens, such as liquid nitrogen or handling large quantities of liquids (> 4L). They do NOT provide adequate protection against high impact hazards, in which case goggles or safety glasses should also be used. Throat protection may be necessary in the presence of chemical reaction set-ups which, because they are large and/or potentially violent and/or of unknown nature, could deflagrate, detonate and send glass and chemicals flying. A blast shield is also recommended in these cases.

\subsection{Foot Protection}

If work involves exposure to hot substances, corrosive or poisonous materials PPE must cover exposed body parts, including legs and feet. Shoes should completely cover the foot, enclosing the whole top of the foot. Thongs, sandals and 'court' shoes are not permitted in the lab. Ideally shoes should NOT be made from material which readily absorbs liquids (i.e. track shoes). Leather is the most widely used upper material because of its versatility, durability and resistance to chemicals. It is desirable to have dedicated lab shoes to prevent contamination in the home environment. This is particularly important if biohazardous material is handled. 


\subsection{Hand Protection}

Hazards to the hand may include:

- skin absorption of harmful substances

- chemical or thermal burns,

- bruises, abrasions, cuts, punctures

- fractures and amputations

There are many types of gloves available today to protect against a wide variety of hazards. Not all glove materials offer equal protection. The nature of the hazard and the activity will affect the selection of gloves. The Ansell glove site lists gloves for a number of specific chemicals- http://www.ansellchemsafe.com/ or Table 1: Common gloves for the laboratory.

\begin{tabular}{|c|c|c|}
\hline Type & Protects against & Do not use with \\
\hline $\begin{array}{l}\text { Butyl gloves } \\
\text { Made of a synthetic rubber } \\
\text { Resist oxidation, ozone corrosion } \\
\text { and abrasion, and remain flexible } \\
\text { at low temperatures }\end{array}$ & $\begin{array}{l}\text { Wide variety of chemicals, such } \\
\text { as peroxide, highly corrosive } \\
\text { acids (nitric acid, sulphuric acid, } \\
\text { hydrofluoric acid and red-fuming } \\
\text { nitric acid). Strong bases, } \\
\text { alcohols, aldehydes, ketones, } \\
\text { esters and nitrocompounds. }\end{array}$ & $\begin{array}{l}\text { Aliphatic and aromatic } \\
\text { hydrocarbons and halogenated } \\
\text { solvents. }\end{array}$ \\
\hline $\begin{array}{l}\text { Natural (latex) rubber gloves } \\
\text { Excellent tensile strength, } \\
\text { elasticity and temperature } \\
\text { resistance. }\end{array}$ & $\begin{array}{l}\text { Most water solutions of acids, } \\
\text { alkalis, salts and ketones. }\end{array}$ & $\begin{array}{l}\text { Can cause allergic reactions. } \\
\text { Hypoallergenic gloves, glove } \\
\text { liners and powderless gloves are } \\
\text { available. }\end{array}$ \\
\hline $\begin{array}{l}\text { Neoprene gloves } \\
\text { Made of synthetic rubber } \\
\text { Good pliability, finger dexterity, } \\
\text { high density and tear resistance. }\end{array}$ & $\begin{array}{l}\text { Alcohols, organic acids, alkalis } \\
\text { hydraulic fluids, gasoline, }\end{array}$ & \\
\hline $\begin{array}{l}\text { Nitrile gloves } \\
\text { Made of copolymer } \\
\text { Good dexterity and sensitivity, }\end{array}$ & $\begin{array}{l}\text { Chlorinated solvents such as } \\
\text { dichloromethane, chloroform. } \\
\text { Oils, greases, acids, caustics and } \\
\text { alcohols. }\end{array}$ & $\begin{array}{l}\text { Strong oxidizing agents, aromatic } \\
\text { solvents, ketones and acetates. }\end{array}$ \\
\hline $\begin{array}{l}\text { Cryogloves } \\
\text { heavy gloves }\end{array}$ & $\begin{array}{l}\text { Tissue damage by cryogens or } \\
\text { very cold containers and } \\
\text { equipment. }\end{array}$ & Not for immersion \\
\hline
\end{tabular}

When selecting gloves consider:-

- type of chemicals handled

- nature of contact (total immersion, splash, etc.)

- duration of contact

- Area requiring protection (hand only, forearm, arm)

- grip requirements (dry, wet, oily

- Thermal protection

- size and comfort.

- abrasion / puncture resistance requirements

Before use, inspect gloves to ensure they are not torn, cut or punctured. A more thorough check can be made by filling the gloves with water and tightly rolling the cuff towards the fingers will help reveal any pinhole leaks. Gloves that are discoloured or stiff may also indicate excessive use or degradation from chemicals. Discard damaged gloves. Disposable gloves should be changed often and not re-used. Any gloves from which hazardous chemical contamination cannot be removed must be collected as contaminated waste. Gloves contaminated with biohazardous material should be handled as biohazardous waste.

Do not wear gloves outside of the laboratory. Gloves should NOT be worn in public corridors, or when touching doorknobs, light switches, telephones or any shared-use item which will be used by others who are not wearing gloves. Always wash hands with soap and water when work is complete. 


\subsection{Clothing}

Long sleeved, fully buttoned up labcoats or wrap around gowns, which are easy to remove, must be used in all laboratories where lab work involves hazardous material. Labcoats help prevent contamination of regular clothes from splashes and toxic material. For PC1 or PC2 labs, where biohazardous materials are handled, back fastening labcoats should be worn.

Skirts and shorts expose part of the leg and this must be taken into account, when assessing the level of PPE needed for any particular procedure.

To reduce the risk of contamination labcoats should be removed on leaving the laboratory and preferably hung on a hook, one labcoat per hook. Labcoats should be washed regularly, using the laundry service and not taken home to be wash with normal clothes. A labcoat which is grossly contaminated with hazardous material must be disposed of as hazardous waste.

\subsection{Respiratory Protection}

\subsubsection{Disposable masks}

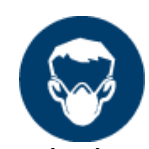

P1 dust masks can be used for non-toxic particulate matter such as silica dust. They should be worn when preparing a chromatography column. Most masks are disposable or have disposable filters, so should not be reused. Read manufacturers instructions before using.

\subsubsection{Half face Respirators}

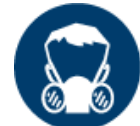

Half face respirators can be used to protect against a variety of particulates, gases and vapours depending upon the cartridges chosen. Cartridges contain filters. These filters rely on sorbent material to "soak up" the gas and vapour molecules. Typically the sorbent is carbon which has been specially treated. Depending on the chemical treatment of the carbon surface, this material will absorb different types of gases or vapours.

Respirator face pieces can be made from rubber or silicone and are required to be tight fitting to ensure proper function. Wearers need to be clean shaven and a fit test is recommended to ensure maximum protection. When purchasing a half face respirator consult with the manufacturer.

When not in use, respirators should be stored in a plastic bag, out of the lab to prevent contamination to the respirator. Cartridges should be dated when put into use and replaced regularly, depending on load and use.

Face pieces can be washed with soap and water, and ideally should not be shared between users.

A useful website in choosing a half face respirator is the $3 \mathrm{M}$ product selector:

http://solutions.3m.com.au/wps/portal/3M/en_AU/OccSafety/Home/Customer_Services/Respirator_Selector/

\subsection{Hearing Protection}

Exposure to excessive noise depends upon a number of factors:

- loudness of the noise, measured in decibels $(\mathrm{dB})$.

- duration of exposure to the noise

- movement between work areas with different noise levels

- if noise is generated from one or multiple sources

Generally, the louder the noise, the shorter the exposure time before hearing protection is required. If engineering and safe work methods do not lower employee exposure to workplace noise to acceptable levels, lab workers must wear appropriate hearing protection. Hearing protectors must reduce noise exposure to within the acceptable limits. Noise is excessive where it exceeds the exposure standard of $85 \mathrm{~dB}(\mathrm{~A})$, over an average of an eight hour period or where a peak noise level of $140 \mathrm{~dB}(\mathrm{C})$ occurs. 
Some types of hearing protection include:

- Single-use earplugs are generally made of foam or silicone rubber plugs. Roll the plug slowly and smoothly into a cylinder. Immediately insert plug into ear canal and hold it in place until it has begun to expand. Aim to get three-quarters of the length of the plug into the canal.

- Pre-formed or moulded earplugs must be individually fitted by a professional and can be disposable or reusable. Reusable plugs should be cleaned after each use.

- Earmuffs require a perfect seal around the ear. Glasses, facial hair, long hair or facial movements such as chewing may reduce the protective value of earmuffs.

Always read instructions from manufacturers before using hearing protection.

\section{Reference Personnel}

All changes to this document shall be referred to the School Safety Committee prior to implementation.

\section{Documentation}

When purchasing PPE ensure OHS requirements are met on the Faculty of Science Order form More details at Purchasing PPE http://staff.uow.edu.au/ohs/safepurchasing/purchasing/index.html\#1

\section{Appendix A: Laboratory tasks, hazards and recommended PPE}

\begin{tabular}{|c|c|c|}
\hline Task & Potential Hazard & Recommended PPE \\
\hline $\begin{array}{l}\text { Working with small volumes of } \\
\text { corrosive liquids ( }<1 \text { litre). }\end{array}$ & Skin or eye damage & $\begin{array}{l}\text { Safety glasses or goggles } \\
\text { Chemically resistant gloves } \\
\text { Lab coat, closed shoes, pants }\end{array}$ \\
\hline $\begin{array}{l}\text { Working with large volumes of } \\
\text { corrosive liquids ( }>1 \text { litre), acutely } \\
\text { toxic corrosives, or work which } \\
\text { creates a splash hazard }\end{array}$ & $\begin{array}{l}\text { Large surface area skin or eye } \\
\text { damage, poisoning, or great } \\
\text { potential for eye and skin } \\
\text { damage }\end{array}$ & $\begin{array}{l}\text { Safety goggles and face shield } \\
\text { Chemically resistant gloves } \\
\text { Lab coat, closed shoes, pants }\end{array}$ \\
\hline $\begin{array}{l}\text { Working with small volumes of } \\
\text { organic solvents }(<1 \text { litre). }\end{array}$ & $\begin{array}{l}\text { Skin or eye damage } \\
\text { Slight poisoning potential } \\
\text { through skin contact }\end{array}$ & $\begin{array}{l}\text { Safety glasses or goggles } \\
\text { Light chemically resistant gloves } \\
\text { Lab coat, closed shoes, pants }\end{array}$ \\
\hline $\begin{array}{l}\text { Working with large volumes of } \\
\text { organic solvents ( }>1 \text { litre), very } \\
\text { dangerous solvents, or work which } \\
\text { creates a splash hazard }\end{array}$ & $\begin{array}{l}\text { Major skin or eye damage, or } \\
\text { potential poisoning through skin } \\
\text { contact }\end{array}$ & $\begin{array}{l}\text { Safety goggles and face shield } \\
\text { Chemically resistant gloves } \\
\text { Lab coat, closed shoes, pants }\end{array}$ \\
\hline $\begin{array}{l}\text { Working with toxic or hazardous } \\
\text { chemicals (solid or liquid). }\end{array}$ & $\begin{array}{l}\text { Potential skin or eye damage, } \\
\text { potential poisoning through skin } \\
\text { contact. }\end{array}$ & $\begin{array}{l}\text { Safety glasses (goggles for large } \\
\text { quantities), } \\
\text { Chemically resistant gloves, } \\
\text { lab coat, closed shoes, pants. }\end{array}$ \\
\hline Working with chemical dusts. & $\begin{array}{l}\text { Skin or eye damage, respiratory } \\
\text { damage. }\end{array}$ & $\begin{array}{l}\text { Safety glasses or goggles, appropriate } \\
\text { gloves, lab coat, closed shoes, pants, } \\
\text { Fume hood or appropriate respiratory } \\
\text { protection (P1 mask or half face } \\
\text { respirator) }\end{array}$ \\
\hline Chemical spill cleanup. & $\begin{array}{l}\text { Skin or eye damage, } \\
\text { respiratory damage. }\end{array}$ & $\begin{array}{l}\text { Safety glasses or goggles, } \\
\text { appropriate gloves, } \\
\text { lab coat, closed shoes or boots if } \\
\text { necessary, pants, } \\
\text { appropriate respiratory protection. }\end{array}$ \\
\hline
\end{tabular}




\begin{tabular}{|c|c|c|}
\hline Task & Potential Hazard & Recommended PPE \\
\hline Working with ultraviolet radiation. & $\begin{array}{l}\text { Conjunctivitis, } \\
\text { corneal damage, } \\
\text { erythema. }\end{array}$ & $\begin{array}{l}\text { UV resistant safety glasses } \\
\text { lab coat, closed shoes, pants. }\end{array}$ \\
\hline Working with cryogenic liquids. & $\begin{array}{l}\text { Major skin, tissue, or eye } \\
\text { damage. }\end{array}$ & $\begin{array}{l}\text { Safety glasses or face-shield for large } \\
\text { volumes, } \\
\text { heavy insulated gloves, } \\
\text { lab coat, closed shoes, pants. }\end{array}$ \\
\hline $\begin{array}{l}\text { Working with very cold equipment, } \\
\text { dry ice or in a low temperature } \\
\text { room. }\end{array}$ & Frostbite, hypothermia. & $\begin{array}{l}\text { Safety glasses, } \\
\text { insulated gloves and warm clothing, } \\
\text { lab coat, closed shoes, pants. }\end{array}$ \\
\hline $\begin{array}{l}\text { Working with hot liquids, } \\
\text { equipment, open flames } \\
\text { (autoclave, bunsen burner, water } \\
\text { bath, oil bath). }\end{array}$ & $\begin{array}{l}\text { Burns resulting in skin or eye } \\
\text { damage. }\end{array}$ & $\begin{array}{l}\text { Safety glasses or goggles for large } \\
\text { volumes, } \\
\text { insulated gloves, } \\
\text { lab coat, closed shoes, pants. }\end{array}$ \\
\hline Instrument repair. & $\begin{array}{l}\text { Eye damage from foreign } \\
\text { objects. }\end{array}$ & $\begin{array}{l}\text { Safety glasses, } \\
\text { no loose clothing or jewellery. }\end{array}$ \\
\hline Metal or woodworking. & $\begin{array}{l}\text { Eye damage from foreign } \\
\text { objects, } \\
\text { lacerations from burrs or } \\
\text { splinters. }\end{array}$ & $\begin{array}{l}\text { Safety glasses, } \\
\text { gloves, } \\
\text { no loose clothing or jewellery. }\end{array}$ \\
\hline Glassware washing. & Lacerations, eye damage & $\begin{array}{l}\text { Safety glasses } \\
\text { Heavy rubber gloves, } \\
\text { lab coat, closed shoes, pants. }\end{array}$ \\
\hline $\begin{array}{l}\text { Working with loud equipment, } \\
\text { noises, sounds, or alarms, etc. }\end{array}$ & $\begin{array}{l}\text { Potential ear damage and } \\
\text { hearing loss. }\end{array}$ & Ear plugs or headphones as necessary. \\
\hline
\end{tabular}

University of lowa

Research Laboratory Hazard Assessment Tool For Personal Protective Equipment Use

http://www.uiowa.edu/ hpo/chemsafety/labppetool.doc [accessed 3/6/09] 